\title{
Carpinteiros teatrais, a crítica e o teatro de revista
}

\section{Theatrical carpenters, the criticism and the magazine theater}

\author{
Beatriz da Silva Lopes Pereira* \\ (D) https:// orcid.org/0000-0002-0653-9782 \\ André Luís Gomes* \\ (D) https:// orcid.org/0000-0003-0950-497X
}

Recebido em: 13/11/2018

Aceito para publicação em: 16/11/2018

RESUMO: Nas décadas iniciais do século $X X$, tanto o teatro popular recitado quanto o teatro musicado deparou-se com contrastes e confrontos que marcaram o surgimento de expressiva preocupação com a valorização do que era genuinamente brasileiro, abordando a questão da nacionalidade e, sobretudo, com uma clara preferência pela discussão e/ou representação de temas que lhe eram contemporâneos, consolidando, assim, a sua identidade e refletindo as dificuldades próprias de seu tempo. Grande parte do que se sabe sobre o cenário teatral e cultural desse período vem de notas, anúncios e crônicas publicadas em jornais e revistas da época, das peças de teatro com alusões metalinguísticas dos romances, contos e livros de memória. O objetivo deste artigo é apresentar alguns desses críticos e comentaristas, que consideramos como carpinteiros teatrais, e analisar uma série de textos com autorias e propósitos diversos, que se referiam a espetáculos, atores e atrizes e casas teatrais do período em questão.

Palavras-chave: Teatro Brasileiro. Teatro de Revista. Crítica teatral. Carpinteiros teatrais

ABSTRACT: In the early decades of the 20th century, both the popular recited theater and the music theater were confronted with contrasts and confrontations that marked the emergence of expressive concern for the valorization of what was genuinely Brazilian, addressing the issue of nationality and, above all, a clear preference for discussion and/or representation of themes that were contemporary, thus consolidating the identity and reflecting the difficulties of that time. Much of what is known about the theatrical and cultural scene of this period comes from notes, advertisements and chronicles published in newspapers and magazines of the time, from the plays with metalinguistic allusions of novels, short stories and books of memory. The objective is to present some of these critics and commentators, whom we consider as "theatrical carpenters", and to analyze a series of

\footnotetext{
* Professora da Secretaria de Educação do Distrito Federal, Doutora em Literatura e Práticas Sociais pelo Programa de Pós-Graduação em Literatura da Universidade de Brasília (UnB). E-mail: blindapereira@gmail.com.

*Professor do Departamento de Teoria Literária e Literaturas (TEL) e do Programa de PósGraduação em Literatura da Universidade de Brasília (UnB). E-mail: andrelg.unb@gmail.com.
} 
texts with different authorship and purposes, which referred to spectacles, actors and actresses and theaters at that time.

Keywords: Brazilian Theater. Magazine Theater. Theatrical Criticism. Theatrical Carpenters

\section{Introdução}

Sabendo-se que não se pode estabelecer uma delimitação muito rigorosa para as épocas históricas em qualquer plano - quer literário, quer social ou político - , o recorte sobre o teatro musicado estabelece vínculos com os tempos iniciais da República, em um período que se estende, na verdade, do início da campanha abolicionista, por volta de 1870, o qual se prolonga até a década de 1920, e mesmo até 1930 , como nos parece pertinente.

Não obstante, em nossa abordagem, é possível denominar esse recorte histórico-cultural de Belle Époque tropical, considerada uma espécie de síntese do século XX, com suas singularidades brasileiras, com os seus encantos e desencantos com a modernidade, sem dúvida, período polêmico e ambíguo, porém igualmente afirmativo, em que o país, entre "angustiado e ansioso para reconhecer certa brasilidade" 1 , busca rever o seu passado e projeta um novo futuro em que, na visão do crítico Roberto Schwarz, tudo parecia "começar do zero: aqui o nacional se constrói por subtração" 2 . Nesse sentido, cada contexto cria novas formas de imaginar o país e tenta apagar o que existia até então; embora, nesse momento, figurassem mais acentuadamente as ambivalências:

[...] parecia ter chegado a hora de buscar modelos de identidade nacional, construídos a partir do sementeiro das especificidades: a então surrada mestiçagem que de biológica vira cultural. [...] o passado a conviver com o presente; maxixe e lundu com música clássica, cordel com literatura acadêmica, transporte acelerado com o ritmo no lombo do burro; um país urbano ladeado pela realidade isolada dos sertões distantes; exclusão social com processos de inclusão; clientelismos combinados a processos até então desconhecidos de institucionalização política e social. [...] período afirmativo na batalha por direitos, pela construção da distinção entre as esferas públicas e privadas, pela luta de reconhecimento da cidadania (SCHWARCZ, 2015, p. 350).

Nas décadas iniciais do século XX, acentua-se o surto civilizatório de urbanização, os avanços tecnológicos mudam radicalmente os hábitos sociais das cidades e os fervores culturais estimulam a procura por novas formas de

1 SCHWARCZ, Lilia M.; STARLING, Heloísa M. Brasil: Uma Biografia. São Paulo: Companhia das Letras, 2015, p. 350.

2 SCHWARZ, Roberto. Nacional por subtração. In: Que horas são? São Paulo apud SHWARCZ, Lilia, 2015, p. 350. 
entretenimento. Nesse contexto, a rua se convertia em local privilegiado, recebendo a moda, o footing, a vida social, mas também as manifestações políticas e as expressões da cultura popular.

Os desdobramentos das transformações tecnológicas, com a difusão da industrialização, dos potenciais energéticos da eletricidade e dos novos meios de comunicação e transportes, tornaram-se um fator cada vez mais decisivo na definição das mudanças e configurações das metrópoles. Assim, as inovações tecnológicas alteravam as estruturas econômica, social e política da sociedade e mudavam, ao mesmo tempo, a condição de vida das pessoas e as rotinas de seu cotidiano, tornando mais confortável e aproveitável o tempo do cidadão - o bonde, o automóvel, o telefone, o fonógrafo, o rádio, o cinema modificavam, desse modo, os ritmos e os ritos de viver e conviver na metrópole. Os indivíduos saíam do recato e discrição dos casarões coloniais e ganhavam as ruas, as praças, os cafés, os bares, os salões, os teatros, os cinemas, as agremiações recreativas. Como parte das rápidas mudanças, o consumo cultural ia impondo-se como valor da modernidade. Por um lado, o usufruir das belas-artes nos salões e teatros: óperas, exposições, recitais, conferências; por outro, gente de vida boêmia e de poucos recursos, buscando novas formas de entretenimento: a mágica do cinematógrafo, o teatro, as rodas de samba e de choro, o carnaval e os festejos de rua, tudo isso ganhava significações especiais no burburinho da urbe. Acrescentavam-se a esses fervores culturais as ideias das vanguardas modernistas, polemizando os seus valores estéticos e "postulando o culto à máquina, à força e ao dinamismo, associado à indústria e à celebração estética da velocidade, da fragmentação e o choque permanente de forças do espetáculo moderno da grande cidade" (SUBIRATS, 1993, p.13).

As experiências com a modernização da cidade, a partir dos avanços tecnológicos e as manifestações artísticas e culturais diversas, entrecruzavam-se nos espaços urbanos em diálogos, aproximações e resistências, pontos e contrapontōs, consensos e conflitos, com as representações sociais tanto na percepção e no comportamento do cidadão da urbe, quanto nos registros de seus artistas.

Ao correr os olhos sobre as crônicas, notícias dos jornais e revistas da época, e sobre os registros da variedade de diversões oferecidas ao público, percebe-se que o consumo cultural da sociedade estava relacionado a um novo modus vivendi compulsoriamente adaptado à metrópole. Nesse sentido, a efervescência, o fugaz, o efêmero, a agitação e a pressa refletiam uma realidade que modificava radicalmente a percepção e a sensibilidade humanas, alterando o imaginário e a subjetividade das pessoas, como bem havia registrado Georg Simmel em seu ensaio "A Metrópole e a Vida Mental", publicado em 19023.

Também Nicolau Sevcenko aponta para essas alterações no comportamento das pessoas, em função da modernização e das influências tecnológicas das metrópoles, em seu estudo "A Corrida para o século XXI", quando registra a relação entre máquinas, massas, percepções e mentes nas décadas iniciais do século

${ }^{3}$ SIMMEL, Georg. A metrópole e a vida mental. In: VELHO, Otávio G. O fenômeno urbano. Rio de Janeiro: Zahar, 1976. 
XX:

Esses dois fatores associados - aceleração dos ritmos cotidianos,
em consonância com a invasão dos implementos tecnológicos, e
ampliação do papel da visão como fonte de orientação e
interpretação rápida dos fluxos e das criaturas, humanas e
mecânicas, pululando ao redor- irão provocar uma profunda
mudança na sensibilidade e nas formas de percepção sensorial das
populações metropolitanas. A supervalorização do olhar, logo
acentuada e intensificada pela difusão das técnicas publicitárias,
incidiria, sobretudo, no refinamento da sua capacidade de captar
o movimento, em vez de se concentrar, como era o hábito
tradicional, sobre objetos e contextos estáticos (SEVCENKO, 2001,
p. 64).

Desse modo, a mudança de comportamento nos hábitos e ritmos pessoais e sociais, entre outros aspectos, resultava em estímulo à interatividade sociocultural: as pessoas precisavam ver e serem vistas, o consumo cultural operava uma transformação radical nos costumes mais provincianos e recatados para um transitar quase que compulsório pelos espaços culturais, como um frenesi na busca pelo entretenimento. Esse fenômeno cultural, denominado por diferentes teóricos de "a revolução do entretenimento" tem como pano de fundo a dissolução ou a descontextualização da cultura popular tradicional.

Em suma, a cultura vira mercadoria e, para compensar o empobrecimento social, cultural e emocional, essa "indústria" fornece fantasia, desejo e euforia. Assim, a efervescência das manifestações e eventos culturais oferecidos ao público, além de outros aspectos, vai promover o deslocamento e o trânsito dos atores sociais pelos diversos espaços culturais da cidade e imprimir novos significados e formas de interação entre as artes, os artistas e o público.

Os reflexos dessas transformações aceleradas e do avanço tecnológico, nas manifestações culturais da época, acabam por ganhar visibilidade na literatura, particularmente por meio dos registros de nossos intelectuais, cronistas, caricaturistas e dramaturgos. Em meio a essas mudanças, a imprensa modernizase, o teatro populariza-se e, além de se constituir como suporte estratégico de circulação do novo a serviço do mercado, também, como espaços midiáticos da modernidade ${ }^{4}$, produzem e reproduzem um olhar crítico e estético (crônicas), mas também dessacralizado (crônicas humorísticas, teatro cômico) acerca do cotidiano da cidade e seus tipos humanos, ora enaltecendo, ora se contrapondo à redefinição do padrão cultural e espacial da cidade.

Nesse aspecto, o artista não é só um observador, um testemunho da sua contemporaneidade, quando capta o instante e o fixa em sua linguagem artística, mas, sobremaneira, um agente formador de opiniões como crítico da cultura e da sociedade de seu tempo.

Assim, estabelecendo-se a ponte entre a cena e a rua, destacamos o Teatro

\footnotetext{
${ }^{4}$ Marshall Berman observa que é da "sensação de viver em dois mundos simultaneamente, que emerge e se desdobra a ideia de modernismo e modernização". In: Tudo que é sólido desmancha no ar. A aventura da modernidade. São Paulo: Companhia das Letras, 2007, p. 26.
} 
de Revista, vertente do teatro musicado, que se consolida como uma das mais férteis e diversificadas experiências culturais da modernidade no cenário teatral brasileiro da belle époque tropical, constituindo-se uma forma de representação privilegiada da história da sociedade brasileira, particularmente naquela época de tantas novidades, contrastes e estranhamentos, a exemplo do que observa o crítico e cronista Benjamim Costallat, escrevendo, pouco depois da Primeira Guerra, com o seu humor irônico:

Vivemos no século da eletricidade. No século da síntese. Sintetizar é reduzir. O telegrama sintetiza o espaço e o telefone sintetiza o tempo. E tudo nos ajuda a sintetizar- o automóvel, a locomotiva, o aeroplano, a telegrafia sem fio... a anedota. Tudo é mais rápido e mais sintético neste século. Até os suicídios [...] (COSTALLAT, 1923, p.160 apud SALIBA, 2002, p. 18).

Ressalte-se, ainda, que se encontra presente, nas décadas iniciais do século $X X$, a herança oitocentista de um teatro preocupado com a nacionalidade e a presença de uma estética realista, que entende o teatro como um dos elementos fundamentais daquela construção e irá valorizar o "grande teatro" e a "alta cultura", vistos como contribuintes do processo civilizatório, como enunciadores de valores estéticos fundados nos moldes europeus. Por outro lado, a diversidade cultural, as apropriações e ressignificações promovidas por grupos de intelectuaiscarpinteiros e carpinteiros teatrais 5 , e por homens livres e menos favorecidos socialmente, que, embora de forma marginal, encontram o seu lugar na atividade teatral e se fazem notar na cena cultural da cidade, articulando-se simultaneamente nesse contexto.

\section{Carpinteiros teatrais: a crítica e as alusões ao teatro brasileiro}

Há muito, a "função civilizatória" do teatro consagrara-se como recorrente discurso de nossos intelectuais e artistas. Tributário da modernidade, o teatro brasileiro vai ganhando contornos variados, fazendo emergir uma multiplicidade de experiências nas relações entre autor, ator, público e mercado, tornando casa vez mais visíveis as características de nossa sociedade e suas contradições. E, nesse particular, o teatro como "escola de civilidade" apresentava contornos diversos.

O cenário teatral brasileiro, entre meados do século XIX e o início do século XX, esteve associado a ciclos econômicos, suscitando a convergência de melhorias em torno das casas de espetáculo (iluminação, bonde, calçamento), para inserir-se no circuito de espetáculos internacionais. O Teatro se constituía em um símbolo visível e aparente do progresso cultural para as elites emergentes e periféricas propiciando por algumas horas o apagamento das distâncias com a Europa

\footnotetext{
5 Tem-se que o termo carpinteiro ligado ao teatro, na acepção aqui referida, surge no século XIX, com o advento do Alcazar, para distinguir aqueles que faziam teatro "ligeiro e digestivo" dos que faziam teatro sério. Denominação associada à situação de marginalidade desses intelectuais e artistas, por estarem fora do circuito hegemônico da cultura de elite, mais especificamente do teatro.
} 
civilizada.

A construção de um teatro e a possibilidade de se assistir às companhias internacionais deveriam oferecer a sensação de fazer parte da nova sociedade (burguesa, liberal, capitalista e técnica). Desse modo, a frequência constante aos espetáculos constituía-se em uma espécie de escola de civilidade.

Grande parte do que se sabe sobre o cenário teatral e cultural desse período vem de notas, anúncios e crônicas publicadas em jornais e revistas da época, das peças de teatro com alusões metalinguísticas dos romances, contos e livros de memória. Compõem uma série de textos com autorias e propósitos diversos, que se referiam a espetáculos, atores e atrizes e casas teatrais. À questão teatral presente nessa produção, espalhada por periódicos e com diversos interlocutores, mesclavam-se informação, opinião, ideologia e imaginação. Joaquim Manuel de Macedo, Machado de Assis, Arthur Azevedo e, no contrapelo, Lima Barreto configuram exemplos de autores que deixaram importantes contribuições a respeito do teatro no Brasil.

Nas suas Memórias da Rua do Ouvidor (1878)6,publicadas em folhetins semanais no Jornal do Comércio, Joaquim Manuel de Macedo reiterava esse pensamento da época do teatro como escola da civilidade:

E o satânico Alcazar, que debalde corrigiu depois em parte as exagerações do desenfreamento cênico, deixou-nos até hoje, e nem sei até quando, sem teatro dramático nacional, ao menos regular. Talvez que alguns pensem que a lamentável falta de bom teatro dramático seja de pouca importância. Positivamente assim não é. No teatro pode-se tomar o pulso à civilização e à capacidade moral do povo de um país. O teatro é coisa muito séria. É a mais extensa e concorrida escola pública da boa ou da má educação do povo (MACEDO, 2005, p. 157).

As críticas de Macedo eram direcionadas em especial ao Alcazar, conhecido como Lírico Francês, em que se apresentavam trocadilhos obscenos, cancãs, atrizes seminuas, os quais moldavam o gosto do público, afastando-o de bons espetáculos: "A influência epidêmica, perniciosa, palustre do Alcazar foi tal que Rossi e Salveni tiveram no Rio algumas noites quase sem público" (MACEDO, 2005 p.157).

$\mathrm{Na}$ sua vasta produção de crônicas (1859-1900), Machado de Assis costumava comentar a cena teatral brasileira, entremeando seus comentários como questões políticas e acontecimentos da semana. Machado afirmava que o teatro se constituía em uma "escola da civilidade" e que, em um país como o Brasil, carente de escolas, todas elas eram bem-vindas.

Esse pensamento dominante creditava ao teatro, ao jornal e à produção literária a função de ilustrar a sociedade e de divulgar os valores burgueses e liberais tão desejados. Segundo Machado, havia em sua época uma preferência do público pelas óperas cantadas em italiano, certo desinteresse pelo teatro dramático e poucos espetáculos nacionais, levando o crítico a tratar com benignidade essa

\footnotetext{
${ }^{6}$ Disponível em: http://www.dominiopublico.gov.br. Edições do Senado Federal. Vol.41, 2005.
} Acesso em: 05 mar. 2016. 
escassa produção "a fim de não levar aflição ao aflito"7.

O público brasileiro acostumado com os espetáculos de ópera tinha transformado a ida ao teatro em um desfile de roupas, em um jogo de ver e ser visto. Essa vida social se apresentava como importantíssima para que os membros da nobreza, da alta sociedade e de setores médios da sociedade (funcionários públicos, advogados, médicos, militares) pudessem, por exemplo, se conhecer e se casar dentro do próprio seu grupo social.

O teatro constituía-se, então, em um espaço de sociabilidade, exibição e de apuração da civilidade. Nessa perspectiva, Machado de Assis associava o interesse do brasileiro pelo teatro à moda, pois ambos tinham as suas regras ditadas por Paris:

Em matéria teatral, orçamos pela alfaiataria: é de Paris que nos chegam as modas. Paris teatral é como os seus grandes depósitos ou armazéns de roupas: tem de tudo, para todos os paladares, desde o mimoso até o sangrento passando pela tramóia. (Ilustração Brasileira, 15 de novembro de 1877) ${ }^{8}$.

De acordo com Scheffel (2011), no início do século XX, os espetáculos teatrais mantinham no Rio de Janeiro o prestígio social, sendo comuns turnês de companhias estrangeiras vindas de Portugal, Espanha, Itália e França, que se aproveitavam dos avanços da navegação, que tinham reduzido, pela metade, o tempo das viagens entre a Europa e a América. As especulações financeiras da época do Encilhamento, os lucros obtidos com o café e o crescimento da máquina burocrática na capital federal criaram, de uma hora para outra, um público diminuto, porém interessado nas coisas do teatro. A maioria dos jornais contava com uma coluna dedicada exclusivamente à arte dramática, com programação, resenha, crítica, reclamações e histórias curiosas que ocorriam nas salas de apresentação.

Na coluna sobre Teatro que manteve na Gazeta de Notícias entre 1894 e 19089, Arthur Azevedo fazia um balanço do número de peças apresentadas no ano anterior: "houve, no Rio de Janeiro, nos teatros propriamente ditos, 1006 espetáculos, sendo: 202 no Recreio Dramático, 234 no S. José, 223 no Apollo, 106 no Lucinda, 95 no Lírico, 54 no S. Pedro de Alcântara e 2 no Éden-Lavradio" (AZEVEDO, 1904 apud NEVES, 2002). Ou seja, uma média de dois espetáculos por noite, em uma cidade com 800 mil habitantes, sendo que 200 mil deles em condições precárias, e um público espectador que não deveria chegar a 3\% da população. Eram muitas as casas teatrais, porém de qualidade questionada pelos artistas que reclamavam da iluminação, da acústica, do comportamento do público ou da ausência dele.

Arthur Azevedo apontava essas situações que depunham contra a nossa

\footnotetext{
${ }^{7}$ ASSIS, Machado de Assis. Ao Acaso (Crônicas da Semana) In: Diário do Rio de Janeiro, 10 de janeiro de 1865. Disponível em: http:/ / machado.mec.gov.br Acesso em: 05 mar. 2016.

${ }^{8}$ ASSIS, Machado de Assis. História de Quinze Dias. Ilustração Brasileira, 15 de novembro de 1877. Disponível em: http://machado.mec.gov.br Acesso em: 05 mar. 2016.

${ }^{9}$ In: Larissa de Oliveira Neves. O theatro: Artur Azevedo e as Crônicas da Capital Federal - 1894-1908. Dissertação de Mestrado, 2002. Disponível em: http://www.bibliotecadigital.unicamp.br. Acesso em: 15 mar. 2016.
} 
civilização: as cadeiras desconfortáveis, a algazarra da molecagem das torrinhas, o barulho vindo do exterior do teatro, a promiscuidade nas galerias, os chapéus das grandes damas que atrapalhavam a visão do espetáculo e a insuficiência de bondes para as casas teatrais, fazendo com que os cocheiros cobrassem preços exorbitantes:

Uma das causas do afastamento do público dos nossos teatros são as massadas a que obrigam as dificuldades de condução. D’antes, para evitar a demora do bonde, as famílias voltavam de carro, os cavalheiros de tilburi, e isso não lhes custava um grande sacrifício. Hoje, só as pessoas abastadas podem rouler voiture; cocheiros de praça tornaram-se de uma exigência feroz e sustentam que depois de certas horas da noite não há tabela: o preço é o que eles quiserem - e não há nada mais desagradável que discutir com cocheiros (AZEVEDO, 1902 apud NEVES, 2002, p. 425).

A imagem de pessoas vestidas com luxo e pompa tendo que se locomover para o teatro de bonde, quem sabe dividindo espaço com aquele um quarto da população de "pés no chão", ou em carros de praça precários e tendo que discutir o preço com cocheiros depois de assistir a uma ópera italiana é representativa daquela "modernidade" problemática. Em uma sociedade que deseja estar pari passu com a Europa, a existência de uma vida cultural noturna denunciava deficiências nos transportes, iluminação e policiamento da cidade.

Narrada pelos cronistas brasileiros da época, essa polêmica talvez se explicasse pela natureza de alguns espetáculos apresentados nessas mesmas casas (números de circo, hipnotismo) que tanto agradavam ao público, ou o aspecto improvisado destas unidades, que não foram projetadas para esse fim, como o Teatro Lírico que "por mais que o atamanquem, não consegue disfarçar o seu aspecto de hipódromo" (AZEVEDO apud NEVES, 2002), ou se explicasse pelo ecletismo do público - deseducado nos chamados cafés-concerto, ou por lembrar um circo, tendo inclusive trapézios no alto de seu teto.

A despeito dessas dificuldades, o Teatro continuava exercendo uma forte influência nos hábitos sociais das classes que podiam frequentá-lo, ditando modas, impondo costumes e criando distinções sociais entre os diferentes segmentos que assistiam às peças. Lima Barreto, por exemplo, mesmo dizendo-se pouco afeito às coisas do Teatro, não deixou de manifestar certas implicâncias com Arthur Azevedo, que, no seu entendimento, "tentara impor-se como dono da opinião acerca dos assuntos do teatro" (BARRETO, 2004, pp. 475-479); e com a municipalidade que armou "um teatro cheio de mármores, de complicações luxuosas, um teatro que exige casaca, altas toilettes, decotes, penteados, diademas, adereços" (2004, p.71).

Para Lima Barreto, o Rio de Janeiro não deveria ter investido em um grande teatro no centro da cidade (debate sobre a construção do Teatro Municipal do Rio de Janeiro), já que estava fadado a ficar vazio, desestimulando os atores e inviabilizando os espetáculos que jamais se pagariam. "Lima Barreto achava que seria mais interessante investir em pequenas salas em diferentes pontos da cidade, inclusive nos subúrbios, oferecendo espetáculos variados e que, aos poucos, 
educariam o público" (SCHEFFEL, 2011, p.189). Obviamente, em uma capital que passava por medidas urbanizadoras, voltadas a dar um aspecto mais moderno à cidade, a ideia de Lima Barreto não encontrava ressonância.

Em suas reflexões sobre o teatro, Lima Barreto via a necessidade de síntese e de estudo para a criação artística. O teatro oferecia ao autor a possibilidade de, no espaço sintético de uma sala de apresentação, colocar em contraste parcelas significativas da sociedade brasileira do período, articulando, em dois tempos distintos, o gosto pelo teatro, como um traço de união que podia oferecer contrastes, continuidades, e a estagnação da vida política e cultural do Brasil. A tão desejada função do teatro como escola da civilidade apresentava contradições, pois a sede de competição e distinção social ganhava força naquele espaço, deixando mais evidentes os aspectos periféricos e dependentes do país.

Em crônica de 1903, intitulada "Ópera ou Circo?", publicada na Revista Tagarela, Lima Barreto comentava a frase do Sr. Antonie, diretor da Companhia Teatral de Gabriele Réjane, sobre o aspecto de circo do Teatro da Velha Guarda.

Contextualizando historicamente, Scheffel sintetiza que esse teatro fora inaugurado em 20 de junho de 1871(2011, p.190), tendo sido utilizado durante mais de uma década pelo Circo Olímpico (1857). Em 1875, por despacho Imperial, passou a se chamar Teatro Imperial D. Pedro II. Em 1890, devido à proclamação da República e para ocultar as suas origens monárquicas, teve o seu nome mudado pela última vez para Teatro Lírico Fluminense - o que não impedia que a população fluminense o chamasse de D. Pedro II. Essas sucessivas mudanças de nomes de um estabelecimento ou de um espaço público (ruas, praças) foram motivadas por episódios históricos marcantes entre meados do século XIX e início do século XX, como a Guerra do Paraguai. Diversos desses nomes novos existiam apenas para municipalidade, pois a população preferia a denominação consagrada pela tradição.

Assim, o Teatro Lírico Fluminense servia para Lima Barreto como um sintoma da superficialidade dessas alterações. Na referida crônica de 1903, Lima Barreto comentava alguns aspetos pitorescos do Teatro da Velha Guarda, como as barras de ferro hercúleas, que atravessavam a sala, lado a lado, denunciando o antigo uso circense do espaço e o detalhe de uma imagem em que heráldicos dragões sopesavam o espadagão da República, que tão bem se justapôs à esfera armilar do Império. A junção ocasional, ou por descuido dos administradores do teatro daqueles dois emblemas, denunciava o entrelaçamento entre o presente republicano e o passado monárquico, pois aquela casa de espetáculos continuava a receber os setores dirigentes do país, os quais, em essência, não tinham mudado, mas apenas sofrido acréscimos de setores emergentes devido às necessidades da cidade letrada.

O Teatro da Velha Guarda revelava, portanto, um interessante jogo de duplos (ópera/circo, monarquia/república), que se confundiam e se mesclavam, sendo que a única diferença existente entre os pares era a nova designação que se opunha à antiga. Era essa dualidade que sintetizava movimentos típicos de nossa vida social, como explicava o cronista: 
Creio que me expliquei mal. Naturalmente acham os períodos acima nebulosos por demais; mas exemplificar-me-ei para melhor compreensão.

Supondo: Largo do Machado, num barracão de quintal, canta-se a Marcha de Cadis, se está o high-life de casaca - que é?

- É o Lírico.

Mas por que é Lírico? Porque... Porque... Porque se está de casaca... Imaginai: no bonde (de ceroula ou não), viajam uma senhora e cavaleiro, ambos trajando vestuários de preço, a soberba capa da senhora faz pedante ao elegante sobretudo do senhor; ao vê-los perguntareis:

- Que diabo! Tão ricamente vestidos em bonde de 200 rs.! Que diabo! Que será?

- É o Lírico, respondo eu. Compreenderam?

É o Lírico sob o aspecto... diga-se... sob o aspecto subjetivo. Sob o aspecto objetivo o símile é perfeito; vejamos: em começo é pleno capinzal, ao depois umas paredes adelgaçam-se formando o barracão de circo, mais depois uma fachada pretensiosa acaba a edificação - eis o Lírico (BARRETO, 2004, p. 66-67).

Scheffel registra ainda que tal dualidade estendia-se aos espectadores que, apesar de frequentarem aquele espaço sofisticado e de pertencerem aparentemente a uma elite, não podiam ocultar alguns índices de pobreza e subdesenvolvimento típicos de um país periférico: assistindo a um espetáculo internacional, vestidos com uma elegância importada ou copiada da Europa, mas chegando num bonde de 200 réis (2011, p.192). A diferença dos pés-no-chão, citados por Bilac em crônica de 1907, para os "sem ceroula" (sem dinheiro) de Lima Barreto é evidente: os pésno-chão, pertencentes aos grupos populares, não podiam esconder sua condição e tinham seu trânsito normatizado nas ruas centrais da cidade, enquanto os "sem ceroula" desfilavam livremente pelos ambientes elegantes, colhendo frutos dessa sua exposição (uma negociata, um casamento vantajoso, um tema para uma crônica mundana).

O jogo sutil das aparências em um teatro que não era teatro e uma elite que talvez não fosse elite (por estarem na periferia do capitalismo e tendo em vista os índices exteriores de pobreza, simbolizados no uso do bonde) evidenciava a pose e a convicção de se estar desempenhando o papel com propriedade. $\mathrm{O}$ cronista procura destacar que o jogo da aparência, palpável no interior do teatro, poderia servir como chave de leitura para outros aspectos da vida social do país. O teatro constituía-se num microcosmos, ou seja, a representação do essencial para suscitar a ilusão de que a vida toda esteja representada na sua expressão integral, técnica essencial do romance de feição realista. O Lírico Fluminense sintetizava setores importantes da sociedade brasileira: "Microcosmos representativo de um sentimento que obsedava o país e que atendia por outros nomes: mania aristocrática, desejo de lustro, cosmopolitismo, high-life, vida elegante, hábitos civilizados" (SCHEFFEL, 2011, p. 192).

E o circo? Existe sempre. Em estando a sala cheia, existem lá: malabaristas de câmbio, acrobatas dos códigos (francês, inglês, 
etc.) écuyers gentis, no patrimônio, equilibristas da corda bamba da vida, e por fim, uma coleção de animais exóticos: papagaios parlamentares; macacos velhos que não metem mão em cumbuca; hidras da oposição; serpentes da intriga; patativas do norte (vulgo meninos prodígios); uniolho biográfico (animal da Polinésia onde o mar toca piston); etc. (BARRETO, 2004, p. 6667).

Ao ir ao Lírico Fluminense entre aqueles jovens que faziam zoada e ironizavam as falsas a parências das casacas mal-ajambradas, Lima Barreto deve ter percebido o poder de síntese que aquele espaço poderia lhe propiciar. Pelos seus corredores escuros e nas suas cadeiras desconfortáveis passaram e continuavam passando comerciantes, políticos, jovens vindos do interior, escritores que compunham a dinâmica da sociedade, incluindo a dinâmica da estratificação social nos diferentes setores do teatro: camarotes, cadeiras, torrinhas e corredores escuros (semelhantes às ruas da cidade, por onde todos circulavam).

Mas não só o Lírico Fluminense, seus espetáculos importados e seu público predominantemente esnobe protagonizaram o cenário teatral da época; outras produções, outros espaços teatrais com público diversificado marcaram a cena do teatro brasileiro.

\section{A "decadência" do teatro brasileiro}

Muito decantada, a partir da República, a "decadência do teatro nacional" tornou-se tema constante nos debates dos intelectuais, dos cronistas, da crítica "especializada", ou anônima, nos principais meios de comunicação com o público que eram os jornais, as revistas ilustradas e os almanaques.

Em uma visada, não só pela imprensa jornalística de fin de siècle, que veiculou inúmeras matérias (comentários, folhetins, ensaios, artigos, notas) aludindo ao estado "complicado" do teatro nacional na época, mas também sobre algumas publicações de intelectuais que exploraram o tema, podemos perceber que esse era um assunto "retemperado" nos debates sobre o teatro nacional, como aponta Vanessa Monteiro (2010) ${ }^{10}$.

Destacam-se, no início do século $X X$, entre tantos literatos e jornalistas ligados à tradição crítica, autores como Henrique Marinho11 e Múcio da Paixão12, que discutiram o tema em livros de 1909 e 1916, respectivamente, livros que serviram de fontes básicas e fundamentais para os pesquisadores da história do

\footnotetext{
10 MONTEIRO, Vanessa Cristina. Retemperando o drama: convenção e inovação segundo a crítica teatral dos anos 1890. Campinas, SP, 2010. Tese de Doutorado. Disponível em: http:/ / repositorio.unicamp.br. Acesso em: 15 mar. 2016.

${ }^{11}$ Henrique Marinho reiterava que a crise do teatro era geral. Portugal e Brasil não eram os únicos países que reclamavam do problema; críticos de outras nacionalidades asseguravam que a arte dramática de seu país estava caminhando para um abismo: "A decadência teatral, porém, é geral. Os escritores de todos os países queixam-se de que o teatro da sua terra já não atravessa o período áureo da prosperidade" (MARINHO, Henrique. O teatro brasileiro. Rio de Janeiro: Garnier, 1909, p. 105 apud MONTEIRO, 2010, p. 43).

12 PAIXÃO, Múcio da. O teatro no Brasil. Rio de Janeiro: Brasília Editora, s/d, p. 513 apud MONTEIRO, 2010, p. 45.
} 
teatro brasileiro ao longo do século XX. Em síntese, os críticos compartilhavam da opinião de que o teatro nacional se encontrava em estado lamentável e deplorável, entregue aos empresários exploradores com vistas ao lucro fácil. Conforme os autores, foram inúmeras as causas (o desprezo dos poderes públicos, a nacionalização da opereta francesa, o público, a imprensa, os empresários, os autores, os artistas) - todos teriam uma parcela significativa de culpa) que concorreriam para o "problema".

Apoiando-se em declarações de escritores brasileiros do século XIX sobre o teatro nacional, como Álvares de Azevedo, na década de 1850, Machado de Assis e José de Alencar, ambos na década de 1870, os autores reiteravam que a "crise" era um assunto antigo, levantado muito antes da virada do século XIX para o XX. Ressaltavam que subsistia certa indiferença do público diante do que era nacional e, por essa razão, notava-se a falta de espectadores para as peças dramáticas brasileiras de autores brasileiros, com assunto brasileiro, representadas por artistas brasileiros. Ao contrário, para as peças do gênero ligeiro, traduzidas e adaptadas por autores brasileiros, havia público de sobra (MONTEIRO, 2010, pp.42-44).

Mais otimista do que Henrique Marinho, Múcio da Paixão, entretanto, acreditava na "regeneração"; dizia ser ela uma fatalidade: "A nossa regeneração artística no domínio teatral há de ser fatalmente, mais tarde ou mais cedo, de acordo com as leis do progresso, que são inevitáveis" (PAIXÃO, 1916 apud MONTEIRO, 2010, p.45). Mais adiante, ressalta:

[...] o certo, porém é que essa anomalia há de desaparecer um dia, quando nas alturas do poder surgirem homens de vontade forte, que se decidam a proteger a Arte criando sobre bases sólidas o nosso teatro, que deverá ser dotado de todos os indispensáveis meios de ação de que ele tanto carece para sair de uma vez da insustentável posição em que se encontra há longo tempo (PAIXÃO, 1916 apud MONTEIRO, 2010, p. 47).

Apesar do traço conservador de suas ideias, Múcio da Paixão apresenta uma postura mais condescendente com relação às operetas e, quanto a isso, compartilha da mesma opinião sustentada por Artur Azevedo. Seria, a seu ver, injusto acusar o gênero brejeiro e alegre de ser um item determinante da situação "declinante", tal como declarado por muitos escritores, em especial Joaquim Manuel de Macedo.

Independente do gênero, para Paixão a arte é possível tanto na opereta como no drama, embora mantivesse a distinção conservadora de que o teatro ligeiro era inferior ao drama e à alta comédia. Na verdade, em sua concepção, o problema era a exploração do gênero alegre e brejeiro, cujos textos mostravam-se acrescidos de obscenidades e cenas pornográficas totalmente sem fundamento e qualquer critério:

Não se diga todo o mal da opereta nem se lance em sua conta todas as misérias que têm infelicitado a nossa cena. $O$ gênero alegre tem por fim divertir e não perverter, nele podem ser admiradas como no dramático os melhores trabalhos artísticos. Se fosse preciso invocar testemunhos teríamos à mão uma infinidade de papéis a que Guilherme de Aguiar, Vasques, 
Martins, emprestaram todo o brilho de seus formosos talentos, conseguindo verdadeiras criações. Na opereta pode-se admirar a arte como no drama, como na tragédia, como na comédia, o essencial é estar o trabalho confiado a um artista de merecimento. [...] Diz-se mal da opereta e a ela se atribuem todos os males simplesmente porque ficou isso em moda, manda a verdade que se proclame. (PAIXÃO, 1916 apud MONTEIRO, 2010, p. 47).

Em seu texto, Múcio da Paixão defende Artur Azevedo das acusações de ser o responsável pelo processo que instaurou a "decadência", por ter sido o maior revisteiro do país. Quando Múcio escreveu seu livro, Artur Azevedo já havia morrido e, por isso, talvez visasse, mais do que a analisar a situação do teatro nacional, a prestar uma homenagem ao grande comediógrafo brasileiro que tanto lutou para a "regeneração" da arte nacional, haja vista a sua insistência para a construção do Teatro Municipal do Rio de Janeiro.

Como se pode observar, devido às suas singulares características, o teatro de revista foi visto como símbolo da decadência do teatro nacional tanto pelos intelectuais do período quanto pela historiografia do teatro brasileiro. A concepção de um teatro decadente se torna corrente98na imprensa de fins do século XIX e início do século XX e, muitas vezes, está atrelada aos gostos populares e por isso desclassificada intelectualmente, como destaca Mário Nunes:

É a revista o gênero teatral por excelência, das classes populares. Vive das magnificências fantásticas (...) e da exploração da comicidade ao alcance de intelectos de cultura rudimentar. Serve-se, por isso, do linguajar da plebe, das expressões e frases que lhes são familiares (NUNES, s/d. p.87 apud GOMES, 2004, p. 138).

A ampla divulgação da imagem da decadência do teatro nacional nesse período foi promovida pela imprensa e apropriada pela historiografia tradicional do teatro brasileiro. José Galante Sousa, um dos autores clássicos dessa historiografia, em sua obra O teatro no Brasil, publicada em 1960, critica o advento do teatro ligeiro como o causador da ruptura do desenvolvimento estético no teatro brasileiro e, portanto, um dos causadores da decadência do teatro nacional. A sua crítica, assim como a de diversos historiadores, a esse gênero e, principalmente ao teatro de revista, aponta um "grande vazio" no período em questão. Essa visão está calcada na valorização da dramaturgia textocentrista em detrimento não só dos elementos que constituem a poética própria do gênero (VENEZIANO, 2013) como também de uma análise mais ampla do teatro como fenômeno cultural, que envolve seus agentes produtores (atores, técnicos, diretores, cenógrafos, donos de teatro e produtores), bem como público e crítica.

Analisando-se as influências exercidas pela imprensa na produção de uma crítica teatral e historiográfica, é possível caracterizar a mídia como uma das esferas de poder que, de certa forma, interferiram no modo como o teatro de revista foi compreendido pela historiografia e na forma como a sociedade daquele período se 
apropriava dos temas presentes nas peças. Porém, a mídia não era um canal apenas para a crítica negativa ao teatro de revista, pois também realizava críticas positivas a algumas peças, influenciando a quantidade de público que formava "enchentes" para assistir aos espetáculos. Além disso, a imprensa era um canal em que os autores dialogavam com os intelectuais.

Um exemplo a ser ressaltado é o de Luís Peixoto, um dos autores do teatro de revista, que enviou uma carta ao Jornal do Brasil em 1916, a propósito da peça Me deixa baiano, de Rego Barros, Carlos Bittencourt e Luís Silva. A peça havia sido elogiada por muitos, o que deu ao famoso autor uma brecha para se expressar sobre a dificuldade em escrever revista e ainda defender autores ligados ao teatro de revista muito criticados na mídia da época:

A revista de ano é, para os que frequentam o teatro sério, um vermute; é, para os que só aplaudem as pilhérias dos compadres e as apoteoses de aparato, um bom copo de vinho à refeição da tarde. De modo que não é fácil como parece fazer revista, (...) Fazer uma revista é colecionar piadas de almanaque, pô-las na boca do compadre; ir a comédias esquecidas nos velhos arquivos, sacudilas do pó e compor cenas inteiras, aproveitando tipos daqui e dali. È relembrar a uma mesa de café, uma graça de revista tal e qual; plagiar e dizer ao maestro que componha uma música para a letra já feita; é empurrar letra numa música que todo mundo conhece e saem assobiando na noite da première... (NUNES, s/d, p.87 apud GOMES, 2004, p. 138).

Cabe, aqui, filtrar das palavras do revistógrafo, não só a influência da mídia no prestígio da revista, mas, sobretudo, a enunciação de uma "carpintaria" - uma poética própria na construção do texto revisteiro, muito distante da lógica do teatro sério, enfatizando que os critérios na avaliação das peças de teatro musicado eram diversos dos que regiam a crítica do chamado "alto teatro", em função da diversidade de objetivos entre essas produções teatrais. Além disso, pode-se perceber, na avaliação do autor, um discurso dessacralizador, por indicar um (des)lugar social de alguns autores do teatro de revista, os "intelectuaiscarpinteiros", marginalizados no calor do debate entre o "teatro sério" e o "teatro ligeiro".

Reforçam, ainda, essas premissas, as peças de Carlos Bittencourt e Cardoso de Menezes, que, apesar de terem alcançado amplo sucesso de público, muitas vezes foram desqualificadas pela imprensa pelo fato de esses autores não serem considerados como homens de Letras. Registre-se, aqui, o exemplo de um artigo do Jornal do Commercio ${ }^{13}$ :

A revista dos Srs. Carlos Bittencourt e Cardoso de Menezes, ontem levados à cena no Glória, não fica de certo aquém das outras obras dos aplaudidos teatrinhos. A parceria, tantas vezes vitoriosa no teatro popular, repetiu seus processos habituais, sem qualquer preocupação de novidade (Jornal do Commercio, 5 dez, 1925).

${ }^{13}$ Jornal do Commercio, 5 dez, 1925. 
Se essa crise era reiterada pelos críticos autores, bem como os questionamentos e as balbúrdias se repetiam no senso comum do meio teatral, os sinais de "apatia", de "descalabro", que os jornalistas e críticos diziam pairar sobre os teatros, pareciam contaminar a imprensa jornalística, já que lamentos não faltavam nas seções e colunas teatrais. No entanto, faz-se necessário tanto realizar uma leitura a contrapelo quanto duvidar das evidências.

Nesse sentido, em estudo mais recente, o pesquisador do teatro brasileiro Fernando Antonio Mencarelli14 apresenta a discussão acerca da "decadência do teatro nacional", tão propalada na virada do século XIX para XX (e que se estende até o marco modernizador do teatro brasileiro, na década de 40 do século $X X$ ), por outro ângulo de visão. Segundo o pesquisador, a questão girava em torno de dois pontos relevantes: a baixa intensidade de montagens de dramas nacionais (a maioria dos dramas representados nos palcos era de autoria estrangeira por companhias dramáticas estrangeiras) e a intensa montagem de peças do gênero ligeiro traduzidas e adaptadas por autores brasileiros. Ora, se a crise se refere ao teatro que se faz aqui no Brasil e ao teatro de autoria brasileira, é preciso fazer uma distinção entre o teatro nobre, o drama e a comedia, e o teatro ligeiro (MENCARERLLI, 1999, p.66).

Por tradição, o gênero alegre e brejeiro considerado "inferior" pelo meio intelectual da referida época e a valorização consistente do sentimento nacionalista (com o advento da República), em detrimento do produto estrangeiro, sustentavase pela tese de que o estado da arte dramática nacional se mostrava mergulhada em uma "crise" - crise nunca antes constatada na história do país. Entretanto, os teatros ficavam lotados no que concernia a representações de dramas e comédias estrangeiros e às montagens de peças ligeiras, nacionalizadas (traduzidas e adaptadas) ou criadas por autores brasileiros. E, nesse particular, um paradoxo: enquanto a produção dramática "inferior" (revistas, operetas, vaudevilles e mágicas) era nacional, a produção dramática "elevada" (drama e alta comédia) era importada; esse contraste não foi bem digerido pelos defensores da Arte nacional. A partir de uns dados numéricos coletados nas próprias crônicas de Artur Azevedo acerca do total de espetáculos ocorridos entre 1896 e 1897, o pesquisador esboça um quadro ilustrativo de como se resumia a situação teatral no Brasil no final do

\footnotetext{
${ }^{14} \mathrm{O}$ pesquisador Fernando Antonio Mencarelli registra que o tema da decadência do teatro nacional já vinha sendo discutido bem antes da virada do século XIX para o XX no meio intelectual brasileiro. O tema da decadência do teatro nacional e a militância em favor de sua consolidação através de uma dramaturgia de valor, à qual Arthur Azevedo se dedicava intensamente, era um dos principais assuntos e uma das principais bandeiras dos intelectuais, críticos ou literatos que se interessassem pelo teatro como forma de manifestação artística e de expressão de uma identidade cultural, nesse período. A tão propalada decadência do teatro nacional, na verdade, não era um assunto novo; já há algum tempo aparecia como séria ameaça diagnosticada por conceituados analistas. O tema vinha sendo tratado periodicamente desde meados do século e reiteradamente relacionado com o advento da opereta e dos gêneros de teatro ligeiro no Rio de Janeiro (MENCARELLI, Fernando Antonio. Cena aberta: a absolvição de um bilontra e o teatro brasileiro de revista de Arthur Azevedo. Campinas, SP: Editora da Unicamp/Centro de Pesquisa em História Social da Cultura, 1999, pp. 63-64).
} 
século XIX:

Quando Arthur Azevedo e seus companheiros estão lamentando a situação de nossos palcos, fazem-no com um olhar pautado pela dualidade que identifica o fracasso de um teatro -sério nacional e outro no sucesso relativo dos gêneros ligeiros. Portanto a decantada decadência é tanto mais lamentada à medida que a visão de seus arautos desconsidera o valor daquele teatro ligeiro. Também revela uma avaliação em que importa mais a origem do produto, sua nacionalidade, do que sua repercussão no público carioca. Fala-se em grande decadência do teatro nacional quando muitas salas estão cheias, sejam as de teatro ligeiro, sejam as de teatro estrangeiro. Quanto mais pautada pelos valores de uma elite cultural que reclama uma arte e cultura nacionais de qualidade, particularmente um drama e uma alta comédia nativos, mais enfática é afirmação de que o teatro no Brasil sofria sua pior crise (MENCARELLI, 1999, p. 63-64).

Na passagem acima, Mencarelli esclarece que essa "decadência" não está diretamente ligada à escassez de espetáculos; pelo contrário, os últimos anos do século XIX e também nas décadas iniciais do século XX apresentaram, ao que tudo indica, um movimento artístico teatral muito agitado e com uma plateia bem numerosa e significativa frequentando as casas de espetáculos fluminenses. Mas é preciso especificar para qual tipo de espetáculo essa plateia se dirigia.

Entre os pontos mais comuns que favoreciam a complexa situação teatral, segundo apontam os autores brasileiros, destacavam-se o interesse comercial dos empresários, a exploração injusta sofrida pelos artistas, bem como a difícil vida enfrentada por eles, a influência francesa, a ausência de autores dramáticos e de obras consagradas, o desleixo das autoridades governamentais para com a arte dramática do país. Repetidas vezes, todas essas variáveis eram divulgadas pelos escritores na imprensa jornalística como as principais causas da "decadência" do teatro nacional, incluindo, conforme diziam, a proliferação desenfreada de um teatro musicado carregado de obscenidades e desprovido de literatura.

Desse modo, o teatro de revista foi visto, por muito tempo, como um fator de decadência na crítica e na historiografia brasileira ${ }^{15}$. Entre as razões que geraram tamanha degradação situam-se a despreocupação com a originalidade literária, o gosto em agradar ao público e a comicidade. Mas, do ponto de vista mais amplo e a despeito da propalada "decadência", os teatros da cidade viveram um período de grande agitação, transformando-se em palco de novas formas culturais. Assim, a permanência e o desenvolvimento de uma tradição cômica, o envolvimento com a produção musical popular e a constituição de um incipiente mercado cultural de

\footnotetext{
${ }^{15}$ A decadência do teatro nacional foi abordada, e ainda se faz presente, na historiografia do teatro. Cf.: SOUSA, José Galante. O teatro no Brasil. Tomo I. Rio de Janeiro: MEC / INL, 1960. Além de José Galante Sousa, outro autor que se dedica à história do teatro é Sábato Magaldi. Em seu livro Panorama do teatro Brasileiro, Magaldi destaca que o gênero ligeiro "quase matou o drama e a comédia". Cf. MAGALDI, Sábato. Panorama do teatro brasileiro. Rio de Janeiro: Ministério da Educação e Cultura/ DAC/ FUNARTE/ Serviço Nacional de Teatro, s/d.
} 
massas configuram apenas alguns fatores que podemos associar à voga do teatro ligeiro no período, contrariando a ideia de um "vazio" cultural na época.

Nesse sentido, assumem vulto, ainda, as importantes constatações de Claudia Braga, no interessante trabalho, intitulado Em busca da Brasilidade: Teatro Brasileiro na Primeira República, no qual a autora questiona a tal "crise", ou a dramaturgia condenada, como pertencente a uma época decadente - que vai aproximadamente da proclamação da República até, em geral, o início da década de 40 do século XX, período associado à degenerescência de nosso teatro - evidenciando, assim, que a produção dramática levada à cena contribuiu com peças de qualidade para o estabelecimento da nossa história dramatúrgica:

[...] A questão é que principalmente do ponto de vista de nossa formação cultural, desde o tempo do Império esteve subjacente ao conceito de civilização das 102europeia brasileiras o mito da erudição europeia, ou seja, descende da aristocrática Corte Imperial a tendência à depreciação, por parte de nossas elites, do produto nacional levado à cena, independente da qualidade que pudesse apresentar. A busca da crise teatral brasileira revelou-se, portanto, inócua. O estudo dos textos dramatúrgicos brasileiros escritos e encenados na Primeira República desvenda um caminho de desenvolvimento artístico seguido por nossos autores, cuja opção preferencial demonstra ter sido a de um teatro popular. Se estas obras mantiveram-se até então olvidadas ou mesmo ignoradas por parte dos estudiosos de nossa história teatral, a explicação provavelmente deve-se, antes de mais nada, ao preconceito das camadas ilustradas quanto às formas mais populares de cultura (BRAGA, 2003, p. 6).

Desse modo, o que a autora problematiza em seu trabalho - e que ilumina a nossa abordagem - é a dicotomia entre a efetiva produção teatral brasileira e o que dela exigia a elite nacional, buscando realizar uma reavaliação da dramaturgia do período em questão. A partir desse entendimento, atesta-se que, em vez do vácuo sugerido pela crítica estabelecida, o país manteve, no período abordado, uma tradição teatral popular, de raízes anteriores ao movimento europeizante trazidos por Ziembinsk, tradição esta que, até recentemente, foi ignorada, ou mesmo estigmatizada pela historiografia erudita de nosso movimento artístico teatral, o qual, do mesmo modo, difundiu julgamentos críticos depreciativos e equivocados ao teatro popular.

Enfim, pode-se constatar que a dramaturgia brasileira circunscrita a esse período, tanto do teatro popular recitado quanto do teatro musicado mais especificamente, deparou-se com contrastes e confrontos que marcaram o surgimento de expressiva preocupação com a valorização do que era genuinamente brasileiro, abordando a questão da nacionalidade e, sobretudo, com uma clara preferência pela discussão e/ou representação de temas que lhe eram contemporâneos, consolidando, assim, a sua identidade e refletindo as dificuldades próprias de seu tempo. 


\section{Referências}

ASSIS, Machado. Ao Acaso (Crônicas da Semana). In Diário do Rio de Janeiro, 10 de janeiro de 1865. Disponível em: http://machado.mec.gov.br Acesso em: 05 mar. 2016.

BERMAN, Marshal; tradução Carlos Felipe Moises, Ana Maria L. Ioriatti. Tudo que é sólido desmancha no ar. A aventura da modernidade. São Paulo: Companhia das Letras, 2007.

BRAGA, Claudia. Em busca da brasilidade: teatro brasileiro na Primeira República. São Paulo: Perspectiva; Belo Horizonte, MG: FAPEMIG; Brasília, DF, CNPq, 2003.

COSTALLAT, Benjamin. Cock-Tail. Rio de Janeiro, Livraria Leite Ribeiro,1923, p.160. Apud SALIBA, 2002, p. 18.

GOMES, Tiago de Melo. Um espelho no palco: identidades sociais e massificação da cultura no teatro de revista dos anos 1920. Campinas/SP: Editora da Unicamp, 2004.

MAGALDI, Sábato. Panorama do teatro brasileiro. Rio de Janeiro: Ministério da Educação e Cultura/ DAC/ FUNARTE/ Serviço Nacional de Teatro, s/d.

MACEDO, Joaquim Manoel de. Memórias da Rua do Ouvidor. Jornal do Comércio, 1878. Disponível em: http://www.dominiopublico.gov.br. Edições do Senado Federal. Vol.41, 2005. Acesso em: 05 mar. 2016.

MARINHO, Henrique. O teatro brasileiro. Rio de Janeiro: Garnier, 1909, p.105 apud MONTEIRO, 2010, p.43.

MENCARELLI, Fernando Antonio. Cena aberta: a absolvição de um bilontra e o teatro brasileiro de revista de Arthur Azevedo. Campinas, SP: Editora da Unicamp/Centro de Pesquisa em História Social da Cultura, 1999.

MONTEIRO, Vanessa Cristina. Retemperando o drama: convenção e inovação segundo a crítica teatral dos anos 1890. Campinas, SP, 2010. Disponível em: http/ / repositório unicamp.br Acesso em: 28 jan. 2017.

NEVES, Larissa de Oliveira. O Theatro de Artur Azevedo e as Crônicas da Capital Federal-1894-1908. Dissertação de Mestrado, 2002. Disponível em: http://www.bibliotecadigital.unicamp.br. Acesso em: 15/03/2016.

PAIXÃO, Múcio da. O teatro no Brasil. Rio de Janeiro: Brasília Editora, s/d, p. 513 apud MONTEIRO, 2010, p.45.

REZENDE, Beatriz e VALENÇA, Raquel. (Org.) Toda a crônica. Lima Barreto. V.2. Ópera ou Circo? Rio de Janeiro: Agir, 2004.

SEVCENKO, Nicolau. A corrida para o século XXI: no loop da montanha-russa. São Paulo: Companhia da Letras, 2004.

SHEFFEL, Marcos Vinícius. Ópera ou circo? Teatro e atraso cultural na visão de Lima Barreto. In: Crítica Cultural (Critica), Palhoça, SC, v. 6, n. 1, p. 183-201, jan./jul. 2011.

SHWARCZ, Lilia; M. STARLING, Heloísa M. Brasil: Uma Biografia. São Paulo: Companhia das Letras, 2015.

SIMMEL, Georg. A metrópole e a vida mental. In: VELHO, Otávio G. O fenômeno urbano. Rio de Janeiro: Zahar, 1976.

SOUSA, José Galante. O teatro no Brasil. Tomo I. Rio de Janeiro: MEC / INL, 1960. 
SUBIRATS, Eduardo. Tradução Eduardo Brandão. A cultura como espetáculo. São Paulo: Nobel, 1989.

VENEZIANO, Neyde. O Teatro de Revista no Brasil: dramaturgia e convenções. São Paulo: SESI-SP Editora, 2013. 